Mitteilungen der Österreichischen Geographischen Gesellschaft,

151. Jg. (Jahresband), Wien 2009, S. 195-214

\title{
Development Patterns of Rural Depopulation Areas Demographic Impacts of Amenity Migration on Italian Peripheral Regions ${ }^{1)}$
}

\author{
Ernst STEINICKe, Innsbruck, Peter ČEDE, Graz, and \\ Ulrike FLIESSER, Peterborough* \\ with 7 Fig. and 1 Table in the text
}

\section{CONTEnTs}

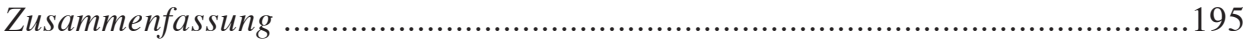

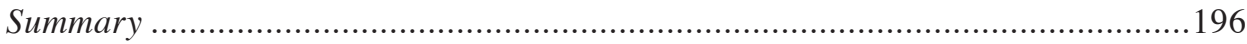

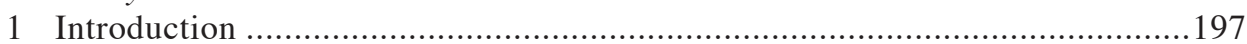

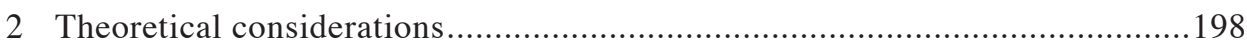

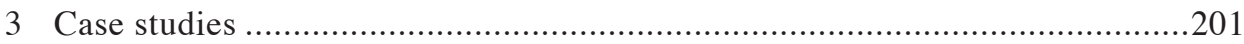

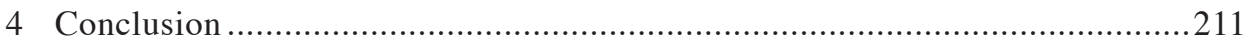

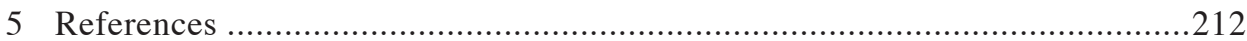

\section{Zusammenfassung}

Entwicklungspfade ländlicher Entvölkerungsgebiete. Demographische Auswirkungen der Amenity Migration auf italienische Peripherregionen

Im Gegensatz zu den Jahrzehnten nach dem Zweiten Weltkrieg hat das Phänomen der Abwanderung aus den ländlichen Peripherräumen in Italien mittlerweile stark an Bedeutung verloren. An seine Stelle trat eine leichte Zuwanderung vorwiegend urbaner Bevölkerung, sodass nach These 1 die natürliche Bilanz zum bestimmenden Faktor der Bevölkerungsentwicklung wurde. These 2 geht davon aus, dass die Entwicklungspfade ländlicher Entvölkerungsgebiete vom Wechselspiel der Faktoren

\footnotetext{
1) The Austrian Science Fund supported research for this article (P20954-G03).

* ao. Univ.-Prof. Dr. Ernst STEINICKE, Institut für Geographie, Universität Innsbruck, Innrain 52, A-6020 Innsbruck; e-mail: ernst.steinicke@uibk.ac.at,http://www.uibk.ac.at/geographie; ao. Univ.-Prof. Dr. Peter ČEDE, Institut für Geographie und Raumforschung, Universität Graz, Heinrichstraße 36, A-8010 Graz; e-mail: peter.cede@uni-graz.at,http://www.uni-graz.at/geowww/geo/neu/; Ulrike FLIESSER, Julian Blackburn College, Trent University, 1600 West Bank Drive, Peterborough, ON K9J 7B8, Canada; e-mail: ulrikefliesse@trentu.ca,http://www.trentu.ca/admin/jbc
} 
Landschaftswert, Freizeitwert und Förderungswert abhängen. Daraus konnten die Autoren drei Typen von traditionellen Entvölkerungsgebieten ableiten, in denen sich das Phänomen der Amenity (-led) Migration - bei zum Teil fließenden Übergängen zwischen Zweitwohnsitzen und Freizeitwohnsitzen - in der demographischen Entwicklung widerspiegelt. In drei regionalen Fallstudien (Orciatal in der Toskana, westliche Dolomiten, Friulanische Alpen) konnte der Nachweis erbracht werden, dass "Amenity Migration" im Sinne nicht wirtschaftlich motivierter Wanderung urbaner Bevölkerung in ländliche Gebiete maßgeblich den aktuellen demographischen Entwicklungspfad der traditionellen Entvölkerungsgebiete beeinflusst. Dabei wurde ersichtlich, dass dieser neue Migrationstyp in jenen Räumen besonders stark vertreten ist, wo ein aus der Attraktivität der persistenten Kulturlandschaft resultierendes Tourismuspotenzial durch öffentliche Förderungen erschlossen oder in Wert gesetzt wurde. Unter Bezugnahme auf die Ergebnisse dort durchgeführter Untersuchungen sind dabei das Orcia- und das Fassatal besonders hervorzuheben. Dass "Amenity Migration” in abgeschwächter Form auch in Gebieten mit nur gering erschlossenem Tourismuspotenzial auftritt, belegt das Beispiel der Friulanischen Alpen.

\section{Summary}

In contrast to the decades after World War II, out-migration from rural peripheral areas in Italy has now markedly decreased. Instead there has been a slight influx of mostly urban residents; therefore, according to thesis 1, the natural demographic balance has taken over as the determining factor in population development. Thesis 2 assumes that trends in rural/peripheral regions marked by depopulation depend on the interaction between several different factors, as well as the quality of each individually: physical surroundings, recreational and leisure facilities, and public funding. Based on these two theses, the authors define three types of traditional depopulation areas in which the phenomenon of amenity-led migration is reflected in demographic patterns - albeit without a clear-cut distinction between secondary residences and recreational homes. Using three regional case studies encompassing the Orcia Valley in Tuscany, the western Dolomite Region, and the Friulian Alps respectively, the authors support the notion that amenity migration has a key influence on the ongoing demographic development pattern of areas previously characterised by depopulation. Through research it has become apparent that this new type of migration is especially prevalent in regions where the potential for tourism, specifically in areas with an attractive traditional cultural landscape, has been developed through public funding. In this context, the Orcia and Fassa Valleys were the focus of on-site research. In areas where the potential for tourism has only been moderately developed, such as the Friulian Alps, amenity migration has developed on a smaller scale. 


\section{Introduction}

Over the past few decades, there has been a divergence in the prolonged, distinct emigration patterns that characterised rural peripheral areas of Europe for much of the $20^{\text {th }}$ century. What is striking about this new trend is the coexistence of birth deficits alongside migration gains. Determining factors for the demographic trends in these areas include the interaction between current agricultural conditions and the traditional cultural landscape, the potential for tourism and tourism infrastructure, as well as public funding for socio-economic and cultural advancement. To illustrate three types of depopulation areas along with their demographic development patterns, the Orcia Valley [Val d'Orcia] in Tuscany [Toscana], the western Dolomite [Dolomiti] region, and the Friulian Alps [Montagna friulana] are examined in this study. The primary objective is to analyse present demographic trends, with a focus on the phenomenon of amenity-led migration.

Industrialisation, as well as tertiarisation and the socio-economic transformation that came with it, turned parts of some rural regions into distinct out-migration areas during the $20^{\text {th }}$ century. Along with remote areas and islands, mountainous regions have been especially affected by this development. Classic European examples of this demographic issue include Scotland's northern regions, the French Massif Central, and vast regions of the Pyrenees, the Apennines and the Alps, as well as islands of the former Yugoslavia. In some of these peripheral areas, severe population problems persisted even after the economic situation improved: large waves of emigration engendered unfavourable bio-demographic structures that caused further population losses. Despite such negative conditions in several of these traditional out-migration areas, however, a demographic reversal has now occurred, which may eventually result in population increases.

Numerous studies focusing on demographic development and economic transformation have been conducted in the aforementioned regions. While LichtenBERGER (1966) cited causes for depopulation of the French Massif Central, for example, the work of BERGOUIGNAN et al. (2005) encompassed the entire territory of France. Areas of depopulation in Italy have also been the subject of past academic publications, by Varotto \& Psenner (2003) and Pascolini (2008), as well as by Kühne (1974) concerning the Apennine region specifically, by Zanini (1968), Tranquilli (1993), Oggiano (1996), ČEDe \& Steinicke (2007) on Friuli, and by Bätzing (1988) on the Piemont Alps. Other important works on the subject include analyses by WeHLing (1982) on the Scottish Highlands, by Schlegel (1995) on the northern regions of Spain, and LAJić \& MišETić (2006) on the Dalmatian islands.

There have been a number of other studies conducted on spatially differentiated developments in various European countries and/or regions. Nevertheless, there remains a scarcity of works that undertake a comparative analysis of the determining factors for demographic persistence and change. In an attempt to close that gap, this paper approaches the question using three case studies as well as several theses to describe the diverse demographic patterns of traditional out-migration areas. In doing so, our primary purpose is to uncover contemporary demographic trends in which 
the phenomenon of amenity-led migration - which still constitutes a novel research project in Europe - plays a central role.

The authors restricted the scope of the regional case studies to Italy because it appeared beneficial to use a uniform territorial-statistical framework. Furthermore, analyses of several Italian regions published by the authors (e.g. ČEDE \& STEINICKE 2007) were already available. Thus, the validity of the findings presented here could be reaffirmed.

This study builds upon results of own research, as well as on two theses that constitute the focus of an ongoing research project at the Universities of Innsbruck and Graz. Apart from evaluating the latest research, this paper was aimed at obtaining information from a range of sources, including open qualitative interviews, interviews with experts, analyses of official statistics, and mapping activities.

\section{Theoretical considerations}

Among the various demographic development patterns in rural peripheral regions of Europe, the trend which emerged as predominant over the course of the $20^{\text {th }}$ century was towards substantial population decline. Socio-economic, cultural and political factors all played a role in this development.

In order to expand on this specific set of problems, we shall first introduce a set of theoretical considerations, which will then be illustrated through case studies. The present study takes two primary theses as its point of departure:

Thesis 1: In many peripheral areas with significant population losses, specifically in Italy, migration deficits will no longer be decisive; instead, bio-demographic factors, such as a higher proportion of older people and declining birth rates, will become more relevant for population development. These depopulation areas will then lend themselves to re-settlement. The primary pull factor for this new process will be amenity-led migration, facilitated both by a favourable real estate market as well as by new forms of telecommunication.

Over the past several years, net migration gains have been registered not only in economically active areas or heavily touristed regions, but also in remote areas marked by depopulation in the past. Initial analyses show that from the mid-1990s onwards, a new demographic trend began to develop in Italian peripheral areas. Since that time, re-settlement of these regions has emerged as an entirely new process (ČEDE \& Steinicke 2007, Steinicke 2008). An ongoing evaluation of demographic trends in all communes of the Italian Alps confirms this new development (BeISMAnN 2009): during the period between 2000 and 2009, an annual net migration surplus of 6.1\%o was registered (Eastern Alps: 5.8\%o, Western Alps: 6.7\%o). Using a distinction based on the level of communal population (see Fig. 1) reveals that in the remote areas of the Alps in particular, a reversal of the previous demographic trend has begun. 
In most parts of the French Alps, this development has already resulted in population growth (COY \& STEINICKE 2006). The current trend towards reverse migration to remote mountain areas of Europe shows marked similarities with the ongoing process of counterurbanisation and amenity migration in the Sierra Nevada Mountains of California (Steinicke \& Hofmann 2004; LöfFLer \& Steinicke 2007).

The phenomenon of amenity migration constitutes a relatively new field of regional mobility research. By this term, Moss refers to people moving into peripheral areas to reside year-round or intermittently, principally because of both actual and perceived greater environmental quality and cultural differentiation of these target areas (Moss 2003 , 2006). Both seasonal/intermittent as well as permanent residents contribute to community expansion in high mountain regions. Therefore, counterurbanisation - the re-discovery and re-evaluation of rural areas as permanent residential and commercial space (cf. BerRy 1976; Löffler \& SteinicKe 2004; Mitchell 2004) - should be considered part of the phenomenon known as amenity migration.

According to Moss (2006), amenity migrants typically come from highly urbanised centres, are motivated by a desire to escape negative metropolitan conditions, and have become acquainted with their new place of residence by past leisure-based experiences. Generally economically active, they need a developed information/ communication support system and relatively convenient access to their new homes. Tourism, however, is not seen as a component of amenity migration. While tourists typically visit their destinations without the intention to reside or earn a living there, amenity migrants intend to settle in their chosen areas permanently, seasonally (one or more periods in a year), or intermittently (moving among their residences more frequently). Nevertheless, tourism plays an important role because it can be viewed as a first step to amenity migration (PRICE et al. 1997; Moss 2006).

Amenity migrants exert both positive and negative effects on their destinations. According to Williams \& Gill (2004), positive effects include the infusion of new economic, institutional, and physical infrastructure capacity into the host region. Negative impacts include unanticipated growth-related stresses on the capacity of local social and health delivery systems, environmental resources, cultural and recreational facilities, retail services, and residential housing supply. One final negative side effect of amenity migration is additional pollution in the form of waste and vehicle fumes, an ever-growing concern within the context of environmental health.

Thesis 2: The development pattern of rural/peripheral depopulation areas depends on the interaction between the following factors:

- Agricultural conditions and maintenance of the traditional cultural landscape, or quality of physical surroundings;

- Tourism potential and tourism infrastructure, or quality of recreational and leisure facilities;

- Public (financial) support for socio-economic or cultural development, or quality of public assistance and funding. 


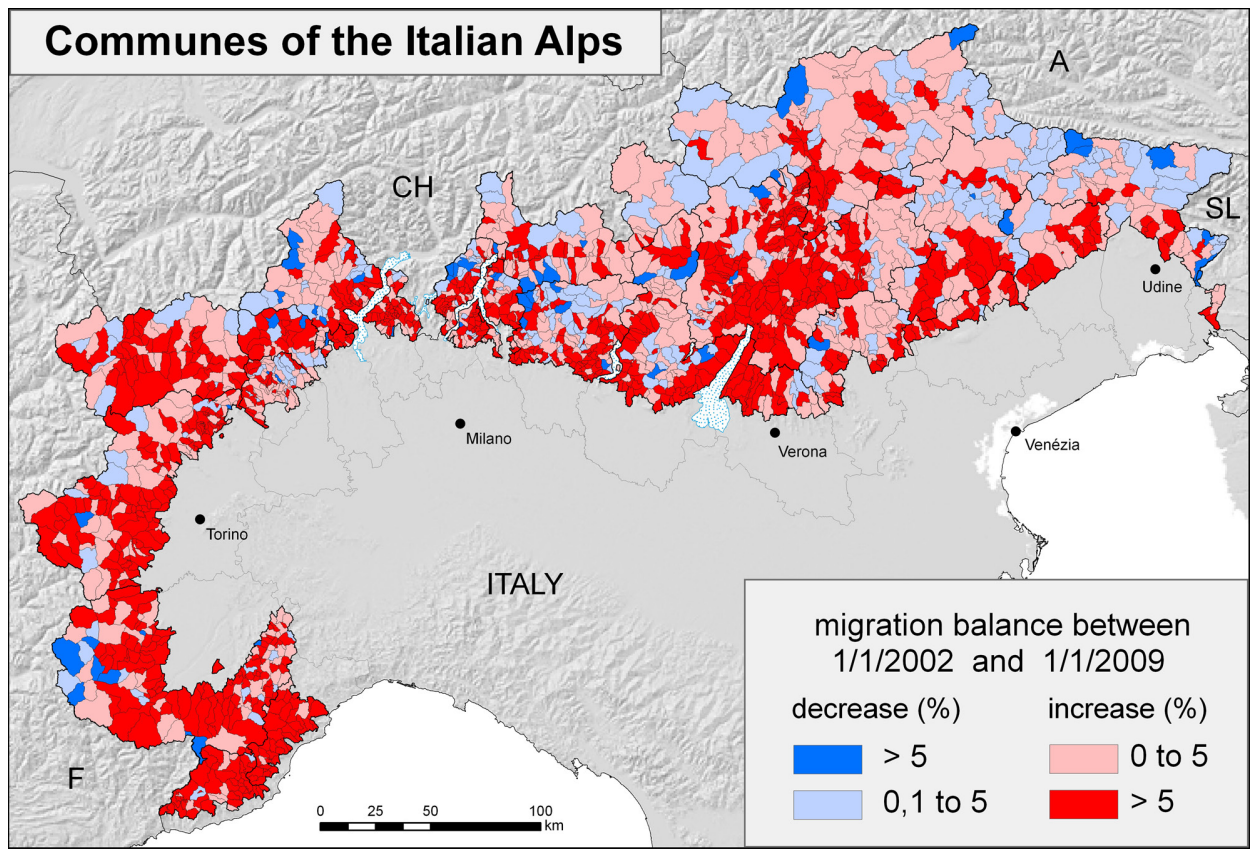

Source: BeISMANN (2009)

Fig. 1: Migration balance in the Italian Alps by communes 2002-2009

By the terms of thesis 2, three principal types of depopulation areas can be defined:

- Areas with high potential for tourism or quality of recreational and leisure facilities along with a well-preserved traditional cultural landscape. Synergistic effects between agriculture and tourism can be strengthened through public funding. If the area becomes more attractive, two follow-on effects are likely to occur. First, tourism could emerge as an additional source of income for the local population. Second, the area's enhanced attractiveness could be an incentive for in-migration, which in turn could lead to a population increase.

- Areas with high potential for tourism or quality of recreational and leisure facilities but largely insignificant agriculture. While public funding can improve the local economy and, in consequence, achieve an increase in population figures, settlement expansion and processes of decline can also occur in parallel.

- Areas with minor potential for tourism or quality of recreational and leisure facilities. In this situation, public funding can do little to induce general economic growth - even in an agricultural environment that is largely intact. Population figures will remain stagnant or even decline, notwithstanding some marginal gains through newcomers. 


\section{Case studies}

In the sections that follow, the three types of depopulation areas outlined above will be analysed through case studies to trace their demographic development.

Although the basic pattern of Type 1 is admittedly seldom encountered, as areas with well-defined tourism potential and intact agricultural structures do not typically fall into the category of depopulation regions, the example of the Orcia Valley in the Tyrrhenic part of the Apennine foothills proves this category is not purely theoretical. Thus our first case study is the Orcia Valley (chap. 3.1). Another example of Type 1 would be the famous winegrowing and tourism region of Wachau in Lower Austria [Niederösterreich], which between 1951 and 1981 registered declining population figures, and only has experienced local population gains from the late 1980s onward.

Type 2 provides a sharp contrast to those examples. In large areas of the Italian and French Alps with high tourism potential, agricultural structures have disappeared to the point where symbiosis with tourism can no longer be achieved. The example of the western Dolomite region demonstrates how a former out-migration area, aided by focused development of the area's tourism potential - in spite of a declining traditional cultural landscape - has developed into an in-migration magnet (Fassa Valley [Val di Fassa]). By contrast, the Livinallongo Valley [Livanallongo] is an example of a Type 2 region where public funding has not been forthcoming at all or only to a small extent, leaving the old demographic structures unchanged.

Type 3 represents the classic characteristics of a depopulation region for which the Friulian Alps are a textbook example. A low potential for tourism combined with unfavourable bio-demographic structures effectively stymie chances for an economic turnaround or expectation of a population increase. Nevertheless, while some of these valleys are losing their last residents at the moment, Northern Friuli as a whole has had more in-migrants than emigrants since the end of the 1990s.

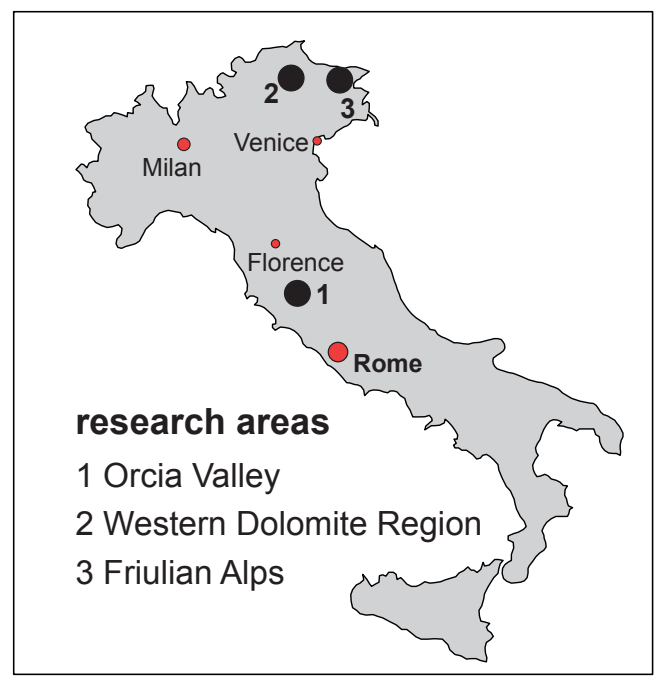

Fig. 2: Location of research focus areas within Italy 


\subsection{Orcia Valley [Val d'Orcia] in Tuscany [Toscana]}

With its historic ties to the former city-state of Siena, the still bucolic landscape of the Orcia Valley ranks among the scenic highlights of Tuscany. In 2004, its five townships of Castiglione d'Orcia, Montalcino, Pienza, Radicofani and San Quirico d'Orcia were incorporated into the list of UNESCO World Heritage sites.

\subsubsection{Context}

The Orcia Valley (pop. 2007: 13,608) is situated in the Province of Siena [Provincia di Siena], approximately $30 \mathrm{~km}$ south of the capital, and was established as the Parco Artistico Naturale e Culturale della Val d'Orcia (Val d'Orcia Nature and Culture Park) in 1999. In physical-geographical terms, the valley belongs to the Tyrrhenic part of the Apennine foothills and thus also to the sand and clay hill landscapes around the scenic Crete Senesi (CASPRini 2006, pp. 7-8; Bazoffi et al. 2008, pp. 586-597; PARCO Artistico Naturale e Culturale della Val d'Orcia 2008a).

As part of the agricultural hinterlands of Siena, the Orcia Valley became the idealised model of a Renaissance cultural landscape during the $15^{\text {th }}$ and $16^{\text {th }}$ centuries. Its idyllic scenery of rolling hills crowned by fortified settlements and edged by cypress boulevards has long been inspiration for artists. Over time these images became a symbol for the 'Tuscan landscape' as a whole.

As a cultural landscape, the valley of the Toscana Urbana is marked by the patterns of isolated farming by the former metayers (mezzadri) that are typical for this region (SABELBERG 1975, pp. 7-30). The persistent structures of the cultural landscape of the Orcia Valley are closely linked to the rise and fall of the city-state of Siena. During the medieval period, the valley was populated in a well-planned manner in accordance with contemporary notions of efficient agricultural production and aesthetics. The foundation for this was the tenure concept of metayage (mezzadria), which regulated the division of authority between urban landlords and their tenants. This structure of property and economy, considered innovative at the time, not only permitted nearequalisation of relations between capital (land owners) and labour (tenants), but also paved the way for a distinct kind of cultivated landscape to be maintained until the mid- $20^{\text {th }}$ century.

With the demise of the city-state of Siena and the simultaneous rise of Florence [Firenze] in the $16^{\text {th }}$ century, the Orcia Valley as well as the rest of southern Tuscany declined in significance. Nonetheless, it appears to be this very loss of status that allowed the cultural landscape to be preserved into the present day. Even Italian agrarian reforms after World War II had only a small effect on the research area.

\subsubsection{Phases in population development}

Stability (until 1951): In the Orcia Valley, as in all parts of Tuscany, the mezzadria system, which goes hand in hand with coltura mista (varied, multi-tiered cultivation methods on each parcel of land), enjoyed extraordinary stability during the first half of the $20^{\text {th }}$ century. SABELBERG $(1975, \mathrm{pp} .36-37,61-65)$ has confirmed that between 1911 


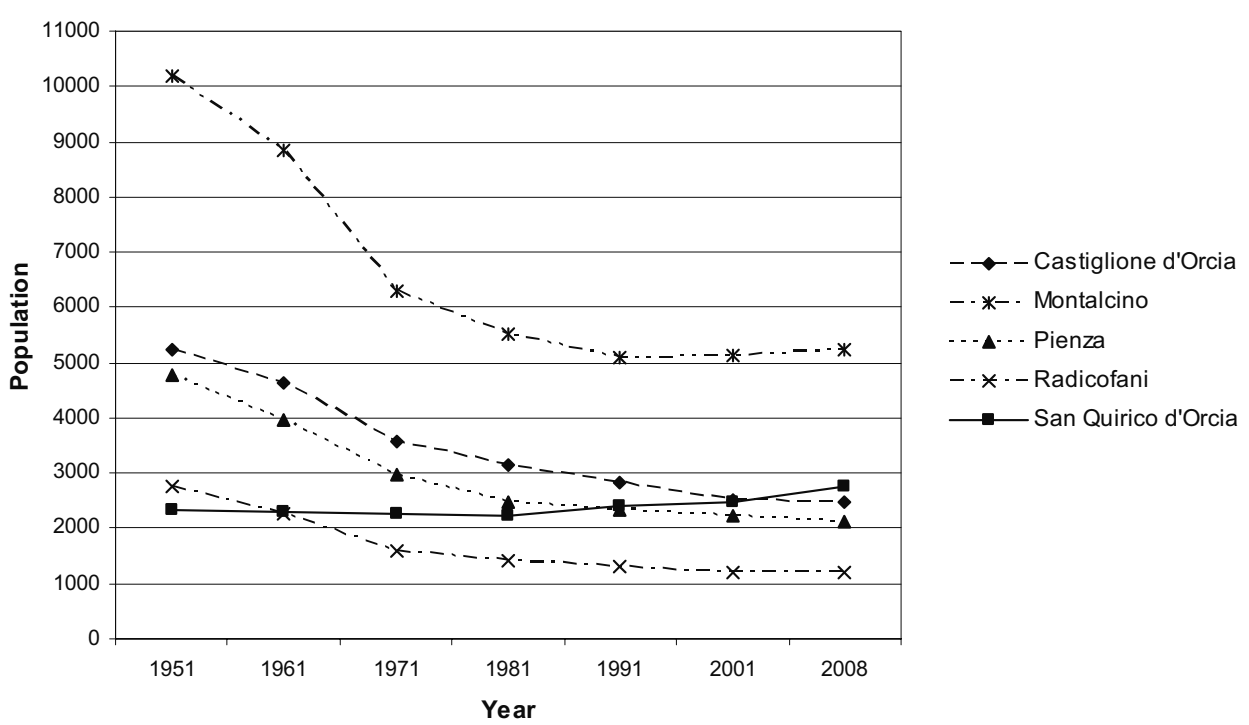

Source: ISTAT 1971ff.; 1985. - http://www.demo.istat.it; presentation by the authors

Fig. 3: Population development in the communes of the Orcia Valley 1951-2008

and 1951, the population of Toscana Urbana exhibited a steady growth of 0.5 percent to 1.0 percent per annum, with a stable age structure. The population of the Orcia Valley in 1951 was $25,277$.

Decline (1951-1981): Triggered by the state's lifting of the mezzadria system, as well as by general socio-economic transformation caused by industrialisation and agricultural reforms, a sudden collapse of economic and social structures occurred. The majority of the rural population was forced to leave the area. Towards the end of the 1970s, early effects of demographic over-aging became apparent (BAzOFFI et al. 2008, pp. 560-598). Relative population losses between individual decades reached double digits almost everywhere. The population had declined to 14,810 by 1981 . Despite the area's scenic attractions, tourism grew slowly. Momentum began to build by the end of the 1970s, however, when first Italian citizens and then foreign nationals discovered the charm of southern Tuscany.

Emergence (1981-2001): With the advent of tourism, there was a slight population influx in the late 1970s and throughout the 1980s. (This development is not reflected in the academic literature.) The negative natural population trend, while counteracting the migration balance, could not completely be offset during this period, and the age structure remained precarious. The nadir was reached when the population dipped to 13,541 . In order to curb population decline and other processes of regression in the area of study, local municipalities began making communal efforts at cooperative development programs by the end of the 1980s. In 1999, this cooperation led to the establishment of a public-private-partnership in the form of the Parco Artistico Naturale $e$ Culturale della Val d'Orcia, which operates under the leadership of a company, the 


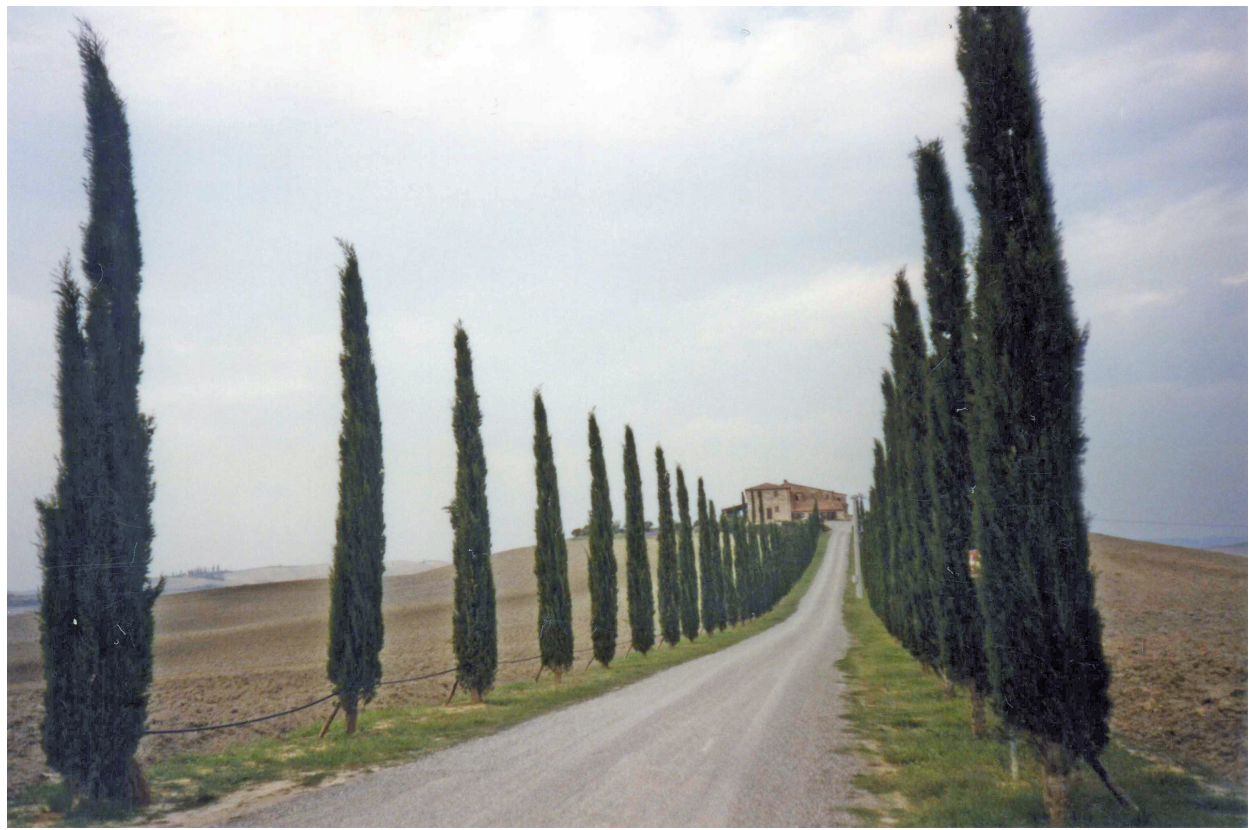

Fig. 4: Traditional cultural landscape in the Orcia Valley. Many farmsteads of former mezzadri now serve either as residences for emigrant urbanites or as facilities for agri-tourism. Given the pull factor of an attractive cultural landscape, most farmsteads have been maintained and only a small number are in danger of collapsing (photograph by the authors, 2008).

Val d'Orcia S.r.I, jointly owned by the five townships within the park boundaries, the Province of Siena, and several private citizens. Its primary objectives for cultivating the landscape's potential include development of ecologically sensitive tourism, stimulation of traditional agriculture, and support for trade and small enterprises (Guido \& Bindi 2006, p. 40; Parco Artistico Naturale e Culturale della Val d'Orcia 2008b).

Growth (since 2001): Apart from the Val d'Orcia Nature and Culture Park, other important factors promoting this most recent development include the designation of the Orcia Valley as a UNESCO World Heritage Site in 2004, and the general regional development strategy of the Province of Siena. Common objectives include the establishment of ecologically sustainable tourism centred on nature and culture (particularly agriturismo for utilisation of farmsteads abandoned by the mezzadri), commercialisation of local high-quality products (Brunello di Montalcino, olive oil, Pecorino), as well as selective infrastructure expansion. An additional economic mainstay of the region is the traditional industry around naturally occurring hot springs, also known as 'thermal tourism' (CAsprini 2006, pp. 5-6, 16-35; Parco Artistico Naturale e Culturale della Val d’Orcia 2008c; 2008d; UNESCO/ICOMOS 2004). 


\subsubsection{Aftereffects}

Despite the persistent problem of over-aging, the Orcia Valley has registered a slight population increase since 2001 as a result of in-migration, particularly over the past several years. Whether settling down in the district or building second homes, new residents have been motivated at least in part by the activities of the Val d'Orcia S.r.I. The company's officials have managed to combine conservation efforts with mindful development of the cultural landscape. Added value has come from quality tourism and superior organic products. Meanwhile, having the status of a UNESCO World Heritage site has helped to promote the Orcia Valley outside of Italy as an 'ideal Tuscan landscape' (CASPRINI 2006, pp. 16-35; GUIDo \& BINDi 2006, p. 40; UNESCO/ ICOMOS 2004).

From conversations with experts, including mayors, as well as from surveys, it was apparent that most of the 'newcomers' in the Orcia Valley come from the mid- and northern Italian central regions. There is also evidence of a large segment of German speakers. Of 38 new residents queried individually, most had visited the area previously as tourists and had come to appreciate its quality of recreational and leisure facilities as well as its high prestige value. Though the majority of persons interviewed were retirees, a number of amenity migrants were working from their new area of residence.

In some respects, the newcomers also represent a potential source of conflict with the original residents, especially where housing prices are concerned (prices of building lots, houses and apartments, as well as rental fees). Affordable living space has become scarce for the locals. Nevertheless, the pace of new construction remains moderate. One reason is the newcomers' preference for historical buildings, though the stringent regulations for preserving the traditional cultural landscape in accordance with UNESCO World Heritage rules also play a role.

Overall, it appears that amenity-led migration in this region may prove capable of curtailing population decline and its associated processes of regression in the cultural landscape.

\subsection{Western Dolomite region: Fassa and Livinallongo Valleys}

\subsubsection{Fassa Valley [Val di Fassa]}

The tourism-focused valleys of the western Dolomites lend themselves as examples of the second type of depopulation area (Andreotti \& Steinicke 2005). Despite the beauty of its rock formations, the Fassa Valley (Italian: Fassa, Ladin: Fascia) had unfavourable agrarian-social conditions which caused a population drain lasting well into the latter part of the $20^{\text {th }}$ century. This out-migration subsided somewhat between the two World Wars thanks to the expansion of mountaineering tourism, while continuous high birth gains contributed to a slight rise in population. In the Dolomites beyond South Tyrol [Südtirol/Alto Adige], but also in other parts of the Italian Eastern Alps, the agrarian way of life had already been abandoned by the time tourism stimulated an economic turnaround. Thus, the symbiosis between mountain agriculture and tourism, 
which was otherwise typical for South and Welsh Tyrolean valleys, did not occur in the Fassa Valley. In the 1960s and even more in the 1970s, regional and provincial agencies took targeted measures to develop tourism infrastructure. At the same time, preserving the Ladin cultural heritage did provide considerable stimulus to tourism in the Dolomite region. The autonomous status of the Trentino-South Tyrol Region [Regione Trentino-Südtirol/Alto Adige] or of the Province of Trento [Provincia di Trento] strongly facilitates government aid earmarked for tourism and culture and has ultimately led to an increase in magnitude of the Fassa Valley's population (cf. LuTZ 2005, pp. 357-363; AndReotti \& Steinicke 2005). Since 1991, the population has increased by more than $9 \%$, and since World War II by more than $44 \%$. The landscape glimpsed alongside the valley roads today is largely one of concentrated patterns of settlement with urban characteristics to some extent. This is a result of increased settlement expansion since the Second World War.

\begin{tabular}{|l|r|r|r|r|r|r|r|r|r|}
\hline Communes & $\mathbf{1 9 2 1}$ & $\mathbf{1 9 3 1}$ & $\mathbf{1 9 5 1}$ & $\mathbf{1 9 6 1}$ & $\mathbf{1 9 7 1}$ & $\mathbf{1 9 8 1}$ & $\mathbf{1 9 9 1}$ & $\mathbf{2 0 0 1}$ & $\mathbf{2 0 0 8}$ \\
\hline Campitello di Fassa & 544 & 514 & 481 & 477 & 588 & 653 & 708 & 732 & 732 \\
\hline Canazei & 901 & 921 & 1036 & 1193 & 1447 & 1608 & 1730 & 1818 & 1848 \\
\hline Mazzin & 465 & 423 & 364 & 370 & 355 & 379 & 422 & 440 & 494 \\
\hline Moena & 2040 & 2000 & 2220 & 2499 & 2688 & 2583 & 2567 & 2602 & 2646 \\
\hline Pozza di Fassa & 1155 & 1092 & 1244 & 1250 & 1426 & 1621 & 1668 & 1787 & 1981 \\
\hline Soraga & 391 & 374 & 439 & 427 & 440 & 519 & 590 & 673 & 677 \\
\hline Vigo di Fassa & 716 & 713 & 720 & 758 & 815 & 883 & 936 & 1037 & 1152 \\
\hline
\end{tabular}

Source: ISTAT 1985. - http://www.demo.istat.it; presentation by the authors

Table 1: Population development in the communes of the Fassa Valley 1921-2008

\subsubsection{Livinallongo Valley [Livinallongo] (German: Buchenstein)}

The eastern adjacent Ladin valley of Livinallongo (German: Buchenstein, Ladin: Fodom), which includes the commune of Colle Santa Lucia (Ladin: Col), has physicalgeographical structures that are similar to the Fassa Valley. Though situated outside the Province of Trento, its potential for tourism has not been realised to the same extent. In the Province of Belluno [Provincia di Belluno], the focus has primarily been on Cortina d'Ampezzo and on San Pietro di Cadore, areas that have been highlighted as tourism centres in need of development aid. It is therefore not surprising that the population figures in Livinallongo and Col since 1921 (pop.: 2,798) - as in the entire Cordevole region - have remained in decline and have currently reached an all-time low of 1,839 (cf. Fig. 5).

The Livinallongo Valley has lost nearly one-third of its residents since World War II. Though out-migration accounted for most of the population decrease until the last two decades, declining birth rates have taken over as the predominant factor since then - a development which can be more clearly observed in Northern Friuli (cf. 3.3). 


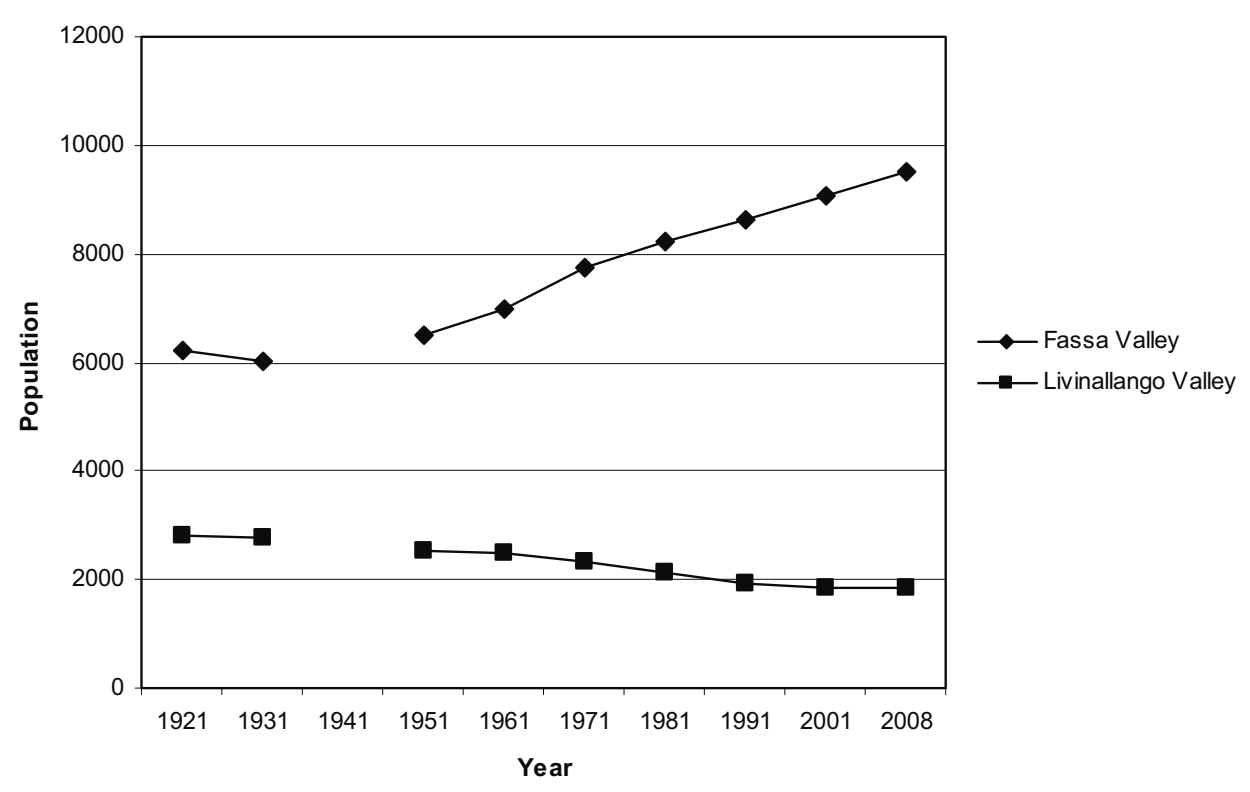

Source: ISTAT 1985. - http://www.demo.istat.it; presentation by the authors

Fig. 5: Population development in the Fassa and Livinallongo Valleys 1921-2008

\subsubsection{Amenity migration in the commune of Mazzin}

This village, located at 1,395 $\mathrm{m}$ above sea level in the transitional region between the central and upper Fassa Valley, is a model case for illustrating the kind of demographic development characteristics of a Type 2 depopulation area. Unlike the other villages in the valley, whose appearance has been profoundly altered by the effects of tourism, the village of Mazzin has largely been able to maintain its traditional architectural character. Being located somewhat off the main tourist track has also helped preserve the traditional agricultural environment for an extended period. Simultaneously, focused regional planning strategies limited new construction of tourist facilities to the village outskirts, while the historic centre underwent renovations. Since the 1980 s, former farm buildings have also been turned into tourist accommodations or even secondary residences.

Today it is only the wooden stables and storage wings of the ancient farmsteads that serve as reminders of the old agricultural way of life. Figure 6 shows these farmsteads have often been renovated into recreational or secondary homes for urbanites from northern Italy, or have otherwise simply been relegated to storage. Currently, fully half of all the old farm buildings have undergone a similar transformation.

According to inquiry results, the number of residents in the 'newcomer' category is 120 (2008: pop. 494; cf. Table 1). In conducting these queries, however, it became apparent that a distinction between amenity migrants and tourists is not always clearcut. Many 'tourists' come so frequently that they are neither strangers to the area, 


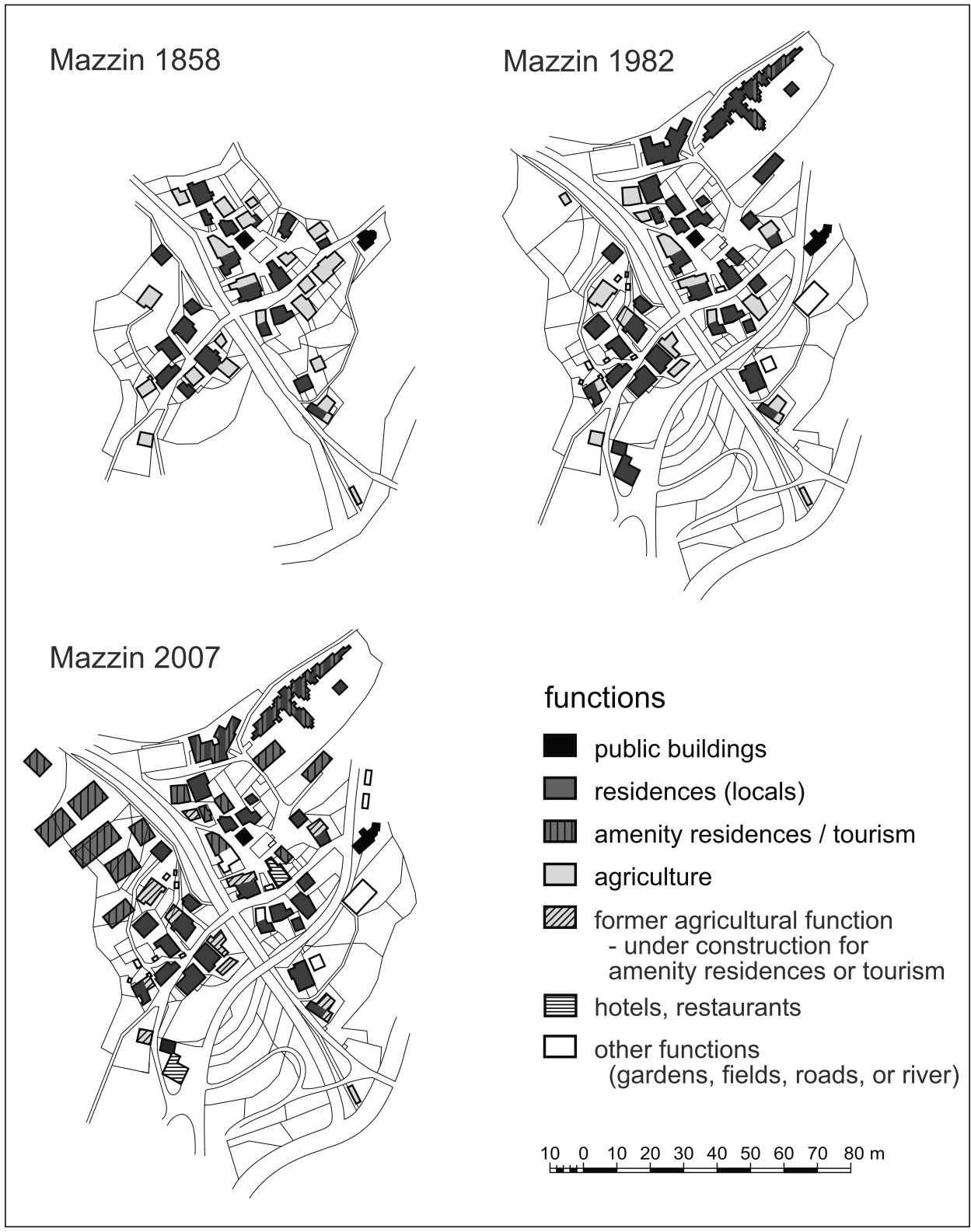

Source: Loss \& VALEnTino 1983, pp. 38-47; mapping by the authors 2004 and 2007

Fig. 6: Fassa Valley: Residential function gradually replaces agricultural function. The example of Mazzin 1858, 1982, and 2007 
nor are they 'consumers' by the usual definition of tourism (see KASPAR 1996, p. 16 or Steinecke 2006, p. 12). At the same time, because owners of secondary residences often come to Mazzin solely to relax and recuperate, no strict differentiation between genuine secondary residences and leisure homes has been made for the purpose of this analysis. For the most part, these newcomers come from larger cities in the Trentino, typically Trento and Rovereto, as well as the Padania cities of Milan [Milano], Verona, Padova and Brescia.

\subsection{Friulian Alps [Montagna friulana]}

In a recently published study, ČEDE \& STEINICKE (2007) characterised the Friulian Alps (Montagna friulana or Northern Friuli) as an area with minimal potential for tourism. Agriculture also plays an extremely marginal role in this region, in conditions similar to the Lower Gurktal Alps [Gurktaler Alpen] in Austria (ČEDE 1991). Meanwhile, other analyses have highlighted the region's extremely unfavourable bio-demographic situation, particularly with regard to over-aging, not to mention the enormous difficulties faced by Northern Friuli's industrial sector at present (e.g. Steinicke 1991; STEINICKE et al. 2007, pp. 558-562).

The Montagna friulana demonstrates a particular pattern of current demographic changes. It has not shared in the economic growth experienced by the foothills and the southern plains since 1970 (STEINICKE 1991, pp. 124-137). Adverse natural and agrarian-social factors in the secondary and tertiary sectors combined with a lack of recreational opportunities were the primary factors behind high rates of emigration, which dominated the demographic picture until approximately 1970 (Friuli migrante). By 1990, the Friulian Alps were one of the regions which had suffered the greatest population losses in Italy since the Second World War. Despite a considerable expansion of job opportunities after the earthquake of 1976 - especially in the construction industry - demographic figures still show a decrease in the population of the mountain regions (1951: 132,827; 2009: 69,994). In some parts of the Friulian Alps there is now a greater number of completely abandoned villages ('ghost towns') than anywhere else in the Alps, despite a population segment of occasional holidaymakers.

Although the larger waves of emigration have now tapered off, they have left behind a skewed ratio of older people to the population as a whole. This in turn has been accompanied by proportionately high death rates and falling birth rates. Given that the prevailing socio-economic development strategies and the demographic situation have not been remedied as yet, and the unlikelihood that a more unorthodox promotion strategy would salvage the situation in the short term, we may assume that depopulation processes in Friuli's mountain region will continue into the future, and 'ghost towns' will remain part of the landscape. 


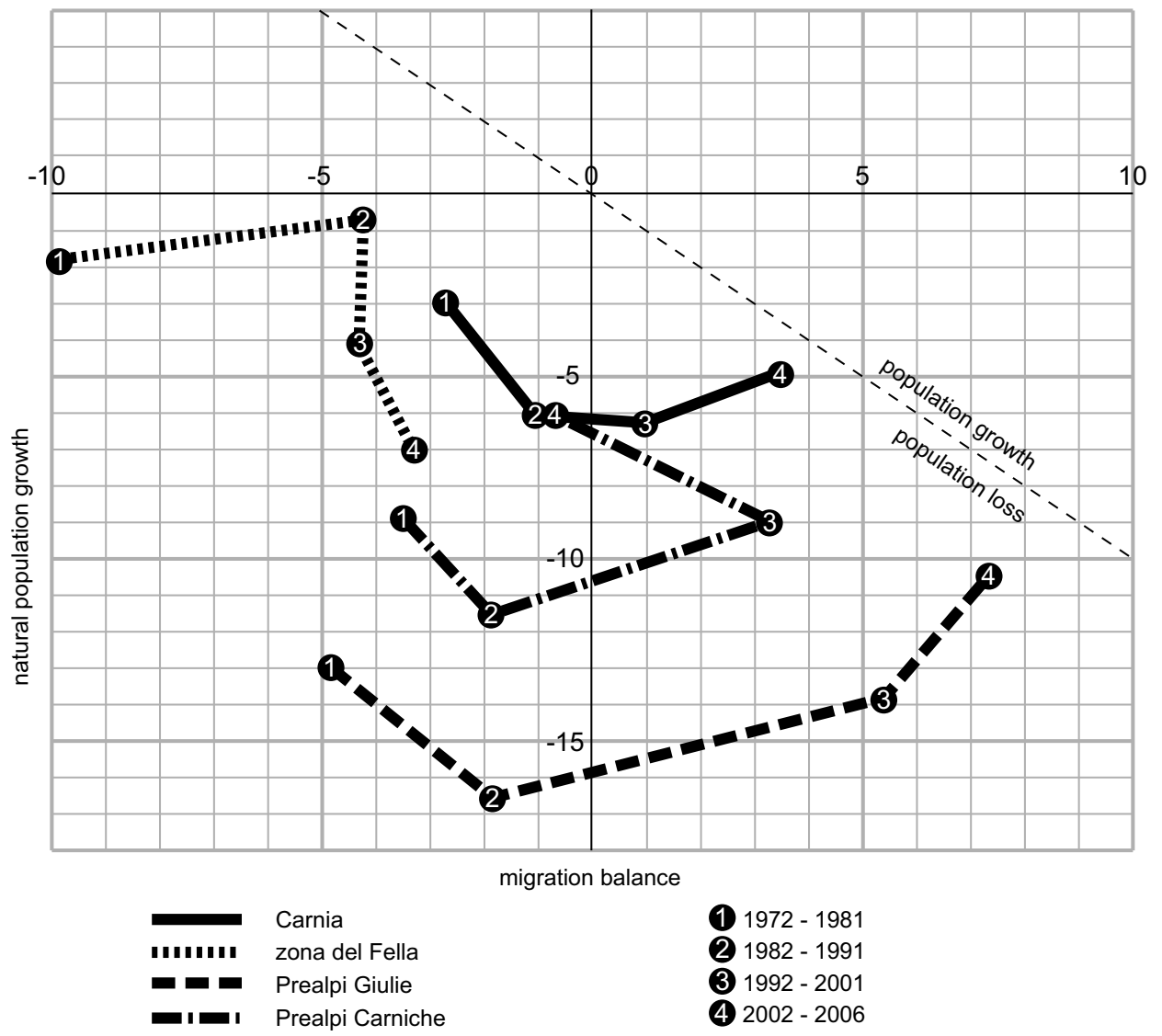

Source: ISTAT 1971ff.; http://www.demo.istat.it; presentation by the authors

Fig. 7: Population balances in the Northern Friulian valleys since 1972 (in \%o)

Nevertheless, we discovered that even in these peripheral areas a demographic countertrend has begun. Analyses of population statistics showed that there is no longer a migration deficit. It is conceivable that the potential for out-migration has been exhausted. Since the end of the 1990s, Northern Friuli has been faced with more in-migrants than emigrants (migration balance 2000-2006: $+2.3 \%$ ). As partially structured interviews in the Resia Valley [Valle di Resia] showed, the newcomers to the Friulian Alps represent an urban community from outside the mountain region (STEINICKe et al.2007). Due to persistent birth deficits, however, this in-migration has not yet resulted in any population gains.

Figure 7 maps this transformation: most of the symbols representing the population balance of the Friulian valleys since 1972 are shifting to the right and upper side of the graph, towards sectors of growing population development. 


\section{Conclusion}

In contrast to the decades following World War II, out-migration now plays a minor role in the peripheral regions of Italy, particularly in the mountainous areas. Most of these territories have now become targets for new arrivals instead. As expressed in thesis 1 , the determining factor in population development is the natural demographic balance. As a rule, significant population growth can only happen in areas with birth surpluses. Nevertheless, in the Orcia Valley, rates of in-migration are high enough to result in slight population growth despite an adverse bio-demographic situation. By comparison, in-migration into the heavily touristed Fassa Valley over the past several decades has brought in mostly younger people, resulting in higher birth rates and a distinct population expansion. However, in Northern Friuli dwindling population figures can only be somewhat offset by the relatively insignificant numbers of in-migrants .

All three research areas substantiated the phenomenon of amenity migration, with its characteristics of demographic development and structure defined at the beginning of this paper. In field studies, however, it was nearly impossible to distinguish between recreation homes and secondary residences, as the determining criteria overlap. Even using narrative interviewing techniques such as personal biographies was not always helpful, as it emerged that a fair number of newcomers own several dwellings that are utilised in different capacities. Although they do not consider themselves tourists, these new additions to the community often make use of their second or third homes primarily for relaxation and, like tourists, make their impact largely as consumers. Classifying residences exclusively on the basis of registration data is not illuminating either, as households with more than one domicile in Italy are often registered under different owners (e.g. spouses, adult children) for tax purposes. It is thus not surprising to learn that the majority of amenity residences are single occupancy. Some properties have also been purchased as an investment, based on speculation in the real estate market.

In the academic literature, there is no consensus on the demarcation between tourism and amenity migration. While B ARTOš et al. (2008) considers a continuous stay of at least one half year the primary distinction, ARNESEN (2008) qualifies the possession of a minimally equipped second abode by itself as the criterion of amenity resident. Milbourne (2007) and Ni Laoire (2007) also debate the permanency of migration. In a special issue of the Journal of Rural Studies $(23,2007)$ they emphasise that not everyone moving to rural places may remain settled in these places. A compilation of the various notions of amenity migration can be found in CHIPENIUK (2008).

However one chooses to define amenity migration/amenity residents, the present analysis has proven to what extent this phenomenon, as described in thesis 2 , influences the development pattern of depopulation areas. From the results of the three case studies, it becomes apparent that amenity migration is particularly high in areas where tourism is already developed, especially in relation to an attractive cultural landscape. Yet impressive scenery alone is not sufficient to arrive at this objective, as proven by the example of the Livinallongo Valley. Stimuli for in-migration are therefore closely linked to a developed tourism sector, which in turn is dependent upon public funding and support. This applies to both the Orcia as well as the Fassa Valley. The model of 
Northern Friuli, however, reveals that the phenomenon of amenity migration can also occur, albeit to a lesser extent, in areas that have embraced tourism only cautiously, if at all. The explanation here can likewise be found in public financing and assistance (cf. STEINICKE 1991): After the 1976 earthquake, a comprehensive reconstruction program was implemented, thanks to support at regional, national and international levels. As a result of this initiative, an abundant supply of suitable housing is still available in the Friulian mountains, which otherwise suffer from the problem of severe demographic over-aging.

\section{References}

Andreotti G., Steinicke E. (2005), Das Fassatal - im Zentrum der Westdolomiten. In: Steinicke E. (eds.), Geographischer Exkursionsführer. Europaregion Tirol, Südtirol, Trentino. Vol. 4: Spezialexkursionen im Trentino und in Ladinien (= Innsbrucker Geogr. Studien, 33/4), pp. 383-415.

ARnesen T. (2008), Recreational home agglomerations in rural areas in Norway as emerging economic and political space. In: Moss A.G., Glorioso R.S., Krause A. (eds.), Understanding and Managing Amenity-led Migration in Mountain Regions, pp. 93-102. Banff.

Bartaletti F. (2004), Geografia e cultura delle Alpi. Milano.

B ARTOŠ M. et al. (2008), Amenity migration in the Czech Republic. Place specific character. In: Moss A.G., Glorioso R.S., Krause A. (eds.), Understanding and Managing Amenity-led Migration in Mountain Regions, pp. 54-64. Banff.

B ̈̈TZING W. (1988), Die unbewältigte Gegenwart als Zerfall einer traditionsträchtigen Alpenregion. Sozio-kulturelle und ökonomische Probleme der Valle Stura di Demonte (Piemont) und Perspektiven für ihre Zukunftsorientierung (= Geographica Bernensia, P 17). Bern.

B ̈̈тZING W. et al. (1996), Urbanization and depopulation in the Alps - an analysis of current social-economic structural changes. In: Mountain Research and Development, 16 , pp. 335-350.

BAZOFFI P. et al. (2008), Field trip guide Val d'Orcia. - http://webdomino1 oecd.org/commet/ arg/soil_ero_bio.nsf/22afaebba539ba74c1256a3b004d5175/e0a07a6038dfc4cac1256b 040058174e/\$FILE/4_field_trip.pdf (accessed August 2008)

Beismann M. (2009), Aktueller demographischer Wandel in den italienischen Alpen (= Thesis at Univ. of Innsbruck). Innsbruck.

Bergouignan C. et al. (2005), La population de la France. Évolutions démographiques depuis 1946. Vol. 1 and 2. XXV Congrès international de la population à Tours (document papier 2005/07/18), Union Internationale pour l'Étude Scientifique de la Population. Paris.

BerRy B.J.L. (ed.) (1976), Urbanization and Counterurbanization. Beverly Hills.

CASPRINI P. (2006), Baseline Review. Managing Urban Europe 25. - http://www.provincia.siena. it/upload/tbl/_centrale/BASELINE_REVIEW1.pdf (accessed August 2008).

ČEDE P. (1991), Die ländliche Siedlung in den Niederen Gurktaler Alpen. Kulturlandschaftswandel im Einzelsiedlungsgebiet unter dem Einfluß des Siedlungsrückganges (= Archiv f. vaterländische Geschichte u. Topographie, 71). Klagenfurt.

Čede P., Steinicke E. (2007), Ghosttowns in den Ostalpen. Das Phänomen der Entvölkerung im friulanischen Berggebiet. In: Geographica Helvetiva, 62, pp. 93-103. 
Chipeniuk R. (2008), Defining Amenity Migration: Results from a Survey of Experts (Participants in 'The Understanding and Managing Amenity-led Migration in Mountain Regions Conference,' Banff, May 15-19). Banff. - http://www.banffcentre.ca/mountainculture/ mtnconferences/am/pdf/survey-results_defining-am-and-am-migrants.pdf (accessed November 2008).

Coy M., Steinicke E. (2006), Regionale Bevölkerungsentwicklung in Frankreich. In: Zeitschrift f. Bevölkerungswiss., 31, 3-4, pp. 537-574.

Guido M.R., Bindi M. (2006), The cultural landscape of the Val d'Orcia. In: BINDI M. et al. (eds.), Documentation for conservation and development - new heritage strategy for the future. $11^{\text {th }}$ Intern. Seminar Florence 2006/09 11-15. Firenze, p. 40.

istat - Istituto Centrale di Statistica (1955ff.), Censimento generale della popolazione 1951, 1961, 1971, 1981, 1991, 2001. Roma.

ISTAT - Istituto Centrale di Statistica (1971ff.), Popolazione e movimento anagrafico dei comuni (Statistiche demografiche / Annuario demografico). Roma. - http://www.demo. istat.it (accessed September 2008).

istat - Istituto Centrale di Statistica (1985), Popolazione residente e presente dei comuni. Censimenti dal 1861 al 1981. Roma.

Kaspar C. (1996), Die Tourismuslehre im Grundriss. $5^{\text {th }}$ rev. and suppl. ed. Bern et al.

KÜHNE I. (1974), Die Gebirgsentvölkerung im nördlichen und mittleren Apennin in der Zeit nach dem Zweiten Weltkrieg (= Erlanger Geogr. Arb., Special Vol. 1).

LAJIĆ I., MišETIĆ R. (2006), Otočni logaritam: aktualno stanje i suvremeni demografski procesi na Jadranskim otocima. Zagreb, Ministarstvo mora, turizma, prometa i razvitka, Institut za migracije i narodnosti.

Lichtenberger E. (1966), Die Agrarkrise im französischen Zentralmassiv im Spiegel seiner Kulturlandschaft. In: Mitt. d. Österr. Geogr. Ges., 108, pp. 1-24.

Löffler R., Steinicke E. (2004), Konsequenzen der Counterurbanisierung im kalifornischen Hochgebirge. In: Mitt. d. Österr. Geogr. Ges., 146, pp. 221-246.

Löffler R., Steinicke E. (2007), Amenity Migration in the U.S. Sierra Nevada. In: Geographical Review, 97, pp. 167-188.

Loss A., Valentino M. (1983), Mazzin di Fassa. Analisi e proposte per il recupero di un centro storico minore del Trentino. Vigo di Fassa.

Lutz W. (2005), Ladinien - Einheit und Vielfalt des dolomitladinischen Raumes. In: STEINICKE E. (ed.), Geographischer Exkursionsführer. Europaregion Tirol, Südtirol, Trentino. Vol. 4: Spezialexkursionen im Trentino und in Ladinien (= Innsbrucker Geogr. Studien, 33/4), pp. 303-382.

Milbourne P. (2007), Re-populating rural areas: Migrations, movements and mobilities. In: Journal of Rural Studies, 23, pp. 381-386.

Mitchell C.J.A. (2004), Making sense of Counterurbanization. In: Journal of Rural Studies, 20, pp. $15-34$

Moss L.A.G. (2003), Amenity Migration: Global Phenomenon and Strategic Paradigm for Sustaining Mountain Environmental Quality. Sustainable Mountain Communities Conference III: Environmental Sustainability for Mountain Areas Impacted by Tourism and Amenity Migration The Banff Centre, Canada, 14-18 June 2003. Banff.

Moss L.A.G. (ed.) (2006), The Amenity Migration. Seeking and Sustaining Mountains and Their Cultures. Santa Fe.

Ni LAOIRE S. (2007), The 'green, green grass of home'? Return migration to rural Ireland. In: Journal of Rural Studies, 23, pp. 332-344.

OgGiano M. (1996), L'Italia alpina di Nord-Est, una analisi demogeografica. Venezia. 
Parco Artistico Naturale e Culturale della Val d'Orcia (2008), The Territory. - http://www. parcodellavaldorcia.com/en/territorio.asp (accessed August 2008).

Parco Artistico Naturale e Culturale della Val d’Orcia (2008b), The Management. - http:// www.parcodellavaldorcia.com/en/gestione.asp (accessed August 2008).

Parco Artistico Naturale e Culturale della Val d’Orcia (2008c), The Bagno Vignoni. - http:// www.parcodellavaldorcia.com/en/vignoni.asp (accessed August 2008).

Parco Artistico Naturale e Culturale della Val d’Orcia (2008d), The Bagno di San Fillipo. - http://www.parcodellavaldorcia.com/en/vignoni.asp (accessed August 2008).

Pascolini M. (ed.) (2008), Le Alpi che cambiano. Nuovi abitanti, nuove culture, nuove paesaggi / Die Alpen im Wandel, neue Bewohner, neue Kulturen, neue Landschaften. Udine.

Price M.F. et al. (1997), Tourism and Amenity Migration. In: Messerli B., Ives J.D. (eds.), Mountains of the World: A Global Priority, pp. 249-280. New York.

Sabelberg E. (1975), Der Zerfall der Mezzadria in der Toskana Urbana. Bedeutung und gegenwärtige Auflösung eines agraren Betriebssystems in Mittelitalien (= Kölner Geogr. Arb., 33).

SCHLEGEL W. (1995), Städtewachstum und Entleerung des ländlichen Raumes in nordspanischen Binnenregionen. In: Geogr. Rundschau, 47, pp. 307-311.

Steinecke A. (2006), Tourismus. Eine geographische Einführung (= Das Geogr. Seminar). Braunschweig.

Steinicke E. (1991), Friaul - Friuli. Bevölkerung und Ethnizität (= Innsbrucker Geogr. Studien, 19).

Steinicke E. (2008), The impact of current demographic transformation on ethno-linguistic minorities in the Alps. In: Borsdorf A., Stötter J., Veulliet E. (eds.), Managing Alpine Future. Proc. of the Innsbruck Conf. October 15-17, 2007 (= IGF-Forschungsberichte, 2), pp. 243-252. Wien.

Steinicke E., Hofmann D. (2004), California's High Mountain Regions as New Areas for Settlement. In: PGM, 148, pp. 16-19.

Steinicke E., Cirasuolo L., ČEde P. (2007), 'Ghost towns' nelle Alpi Orientali. Il fenomeno dello spopolamento nella zona montuosa del Friuli. In: Rivista Geografica Italiana, 114 , pp. 549-570.

Tranquilli D. (1993), Un progetto per la montagna friulana. In: Barazzutti C. (ed.), Irrestibilmente attratti dalla pianura. Il degrado dell'economia e della società montana del Friuli. - Udine, pp. 191-260.

UNESCO (ICOMOS) (2004), Evaluation of cultural properties. Prepared by the International Council on Monuments and Sites (ICOMOS). - http://whc.unesco.org7archive/2004/ whc04-28com-inf14ae.pdf (accessed August 2008).

V arotto M., Psenner R. (eds.) (2003), Spopolamento montano: cause ed effetti / Entvölkerung im Berggebiet: Ursachen und Auswirkungen. Belluno.

WeHLING H.W. (1982), Strukturwandel ländlicher Siedlungen im schottischen Hochland. Gegenwärtige Tendenzen und zukünftige Perspektiven. In: Geogr. Zeitschrift, 70, pp. 127-144.

Williams P., Gill A. (2004), Shaping Future Resort Landscapes: Amenity Migration's Impact on Destination Sense of Place: A Case Study of Whistler, British Columbia. Leisure Futures 2004: $2^{\text {nd }}$ Biennial Conf., 10-12 November 2004. Bolzano.

Zanini F. (1968), Friuli Migrante. $2^{\text {nd }}$ ed. Udine. 